\title{
In the Family? The Inter-relationship of Art and Craft Teachers.
}

\section{Gudrun Heigadottir}

Note: In this paper names are treated according to cultural norms so that Icelanders are referred to by first name first and listed alphabetically under their first name.

\section{Introduction}

The way in which the visual arts are defined and designed in formal curricula as school subjects varies throughout the world. The Nordic countries have an elementary school curriculum tradition in which art has cousins; textiles and wood and metalwork. This grouping is closer to the British model of art and design and to the current art, design and technology than to the prevalent tradition in North America where a schism exists between fine visual art and industrial art, or technology. The contemporary configuration of the subjects such as their degree of integration varies between individual Nordic countries. For instance, Norway has fully integrated art and crafts into one school subject called forming, whereas Iceland has three distinct subjects which share a name and official curriculum goals. A basic assumption in the formal curriculum is that the three subjects are related branches of a family tree of school subjects (Adalnamskra Grunnskola 1977, 1989, Nordic Art Teacher Union 1987, B.C. Ministry of Education 1985, Washington State Technology Education Curriculum Development Project 1990).

In this paper I discuss on one hand the curriculum identity of the subjects that is suggested by the formal curriculum, and on the other that which teachers of the subjects assume. It is widely recognized that the formal and lived curricula are separate but related entities (Eisner 1982, Goodlad and associates 1979, Zais 1976). The curriculum identity that the teacher assumes is crucial in understanding the relationship between formal and lived curricula as the teacher is the mediator between the two levels. The importance of this is underscored by studies which show teachers as either rejecting (Dow, Whitehead \& Wright 1984) or actively adapting and developing curriculum to the extent that they can be seen as having a personal curriculum (Barone 1983, Berliner 1984, Doyle \& Ponder 1977. Fullan 1982, Gray \& MacGregor 1987). My discussion here is limited to the relations between the school subject cousins; art, textiles and wood and metalwork. My concern is how the school subject art and crafts in Iceland 
relate or do not relate to one another. This relationship is manifested on one hand in curriculum documents and on the other in the life histories of art and craft teachers.

\section{Overview of the Study}

This paper is based on my dissertation that goes by the working title "The meaning of the subject; Art and craft teachers' curniculum identity as reflected in life histories". The data, or evidence, as the historian would have it, is from three main sources;

* Oral testimony in the form of professional life histories elicited through interviews.

* Documentary evidence--mainly curriculum documents, education acts, journal articles, textbooks and other instructional material.

* Objects produced in the context of teaching and leaming or using the skills and knowledge generated through the subjects.

The first category, the oral testimony, forms the bulk of my evidence and the other two are complementary.

By curriculum identity I mean the professional identity conferred on the teacher by the subject he or she teaches. A school subject is not simply a curriculum construct. It also encompasses a community of individuals engaged in its practice; students, parents, advocates and teachers. Teachers form the core of this community through their sustained commitment and involvement in the subject. This condition also makes them the most logical choice as informants for a historical study that seeks to go beyond the printed remains of $\theta$ ducational discourse. This is, in part, inevitable because that discourse contains a resounding silence about art and craft.

To document this history I invited certified art and craft teachers in Reykjavik, Iceland to be interviewed about their lifelong relationship with the subject they chose to teach. In the selection I ensured representation from all three subjects, ranging from the first cohorts of certified art and craft teachers to the latest, men and women, from those specializations where both genders are present.

The purpose of the interviews was to document the lifelong relationship that teachers have with their chosen subject. Each interview opened with an invitation to describe the teacher's first memories of the subject at home or in school. The teacher was asked to proceed chronologically from these early memories to the present day. in most cases 
a narrative unfolded without my prompting, but the interviews were semistructured in that I ensured that certain predetermined topics were

discussed. For instance, I almost invariably had to ask the teacher to state the rationale for the subject, and its value for students. Analysis of the interviews focuses on the effects of gender and subject specialization on the teachers' curriculum identity.

\section{Curricular Traditions}

Documentary evidence such as curricula and published educational discourse suggests three traditions of art and craft as we know the subjects today; the vocational, the pedagogical and the aesthetic.

The vocational tradition is different in Iceland than in other western societies because of the low level of industrialization throughout our history. The Icelandic economy is still resource rather than industry based and although vocational rationales surface in the educational discourse, their material base is in the trades rather than industry. Textiles are an exception here, in that this subject had the vocational relevance of preparing girls for the role of a housewife (Gudrun Heigadottir 1993, 1991, Petterson \& Asen 1989).

The aesthetic tradition refers to curricula rationalized on the creation and appreciation of art and crafts. I subsume folk and fine arts under the label of aesthetic tradition. It differs from the vocational in that, its rationales are not job-related but rather related to perceptions of the quality of life. The romantic notion of the artist as genius, the artist as outside social and familial relations as well as the notion of morally beneficial effects of art appreciation are tenets of this tradition.

The pedagogical tradition arose when proponents of mass education were faced with the task of devising and implementing curricula and instructional methods for large groups of lower class children. In this framework the school subjects had precious little to do with art or craft as practiced in the cultural context. Rather they were conceived as having pedagogical value contributing to the overall development of the child. This value was articulated by pedagogues and transmitted by teachers in schools. In the process art and crafts were transformed into school knowledge which is distinct from common knowledge. This is part of the legitimization pattern of schooling.

It is important to note that art and the craft subjects have differed from the outset. The official curriculum rationales may have become progressively 
more similar, but the subjects are steeped in different traditions-- art in the aesthetic, craft in the vocational.

\section{Historical Context}

The public elementary school system in Iceland is relatively young by European standards. This is due to the predominantly rural character of Icelandic society until the early 20 th century. Up to that point, Iceland was a traditional, semi-feudal farming society. Public elementary schools were founded in towns in the late 19th century and the first public school act passed in 1907 . Drawing and crafts were taught sporadically from the early schooling attempts but depended on the interests and abilities of individuai teachers. Drawing was made compulsory in 1926 and crafts--that is textiles for girls and wood and metalwork for boys, were mandated in 1936.

The first specialist teacher training program in wood and metalwork was founded in 1939 as the first program of instruction of the School of Crafts. A program for art teachers was added a couple of years later, then a training program for textile teachers in 1947. All these programs were initiated within the School of Crafts, which today is the Icelandic College of Art and Crafts. The craft teacher training programs were moved to the Teachers' College in 1951, but the art teacher training program remained with the art college until 1986. This institutional shuffle, which apparently was a matter of resource management rather than educational rationalization, has had lasting impact on the profession (Althingistidindo 1947, Lydur Bjornsson 1981, Bjorn Th. Bjomsson 1979, Bjarni Danielsson, Gudrun Helgadottir and Skulina Kjartansdottir 1982).

The status of the subjects within the elementary school curriculum is best described by noting that they are universal, that is compulsory for all students in grades 3-9. They are to be taught by specialists in specialized facilities. Basic materials are provided to the students free of charge. The current time allotment is $\mathbf{1 8 0}$ minutes per week for the three subjects combined, and they should be part of an integrated curriculum in the primary grades (Adalnamsskra Grunnskola 1989, Vidmidunarstundaskra 1993).

Despite this sizable allotment of instructional time and resources, the subjects are not central in the curriculum. They are not part of the national assessment of graduation requirements from elementary school, nor does school based assessment in art or craft in any way affect students' progress through the grade levels of elementary school. In general parlance, the subjects are deemed beneficial but not essential. 


\section{Curriculum Identity}

The interviews suggest that art and craft teachers have deveioped different curriculum identities, and that difference cannot be readily related to the traditions discernible in official curricula. It can better be explained by reference to the dichotomy between the private and the public spheres. The idea of human society having separate spheres of public and private is quite central in western thought and can be traced back to the ancient Greek concept of the oikos and the polis (Rosenberg 1982). The Marxist notion of productive and reproductive spheres is a parallel characterization. This dichotomy has been wanting in many ways (Ehistain 1981). Despite its flaws it is illuminating in this case.

Both art and craft teachers professed a deep need to make things, to produce objects. The context of that production differs. Art teachers identify with artists and the world of professional artists and exhibitions. Gratification is received from the acknowledgment of an external public such as gallery owners or attendees, consumers and critics. Craft teachers identify themselves with the handiperson, the person who can fix and make things about the house. Art teachers identify with a role in public life, whereas the craft teachers, men and women, focus on the private or domestic life.

The artist-teacher identity that the art teachers assume is based on a notion of the male artist's professional life with its need to compartmentalize public and private spheres. Art is made in the studio, where the artist works uninterrupled. It is a place of work in a public rather than private sense. Many of the art teachers I interviewed rent studios, but most were torn between family, teaching and artmaking and found it hard to spend any time producing art in the studio. Whereas the art curricula have followed the aesthetic rather than vocational tradition, the art teachers live by a concept of the artist's vocation

The craft teachers, men and women, found ways to satisfy their need to produce crafts that harmonized more with their family responsibilities. They rarely had a work space separate from their home. Their workshop might be in the basement or in the garage, but on the premises of their home. The presence of their children or other family members was seen as integral to the project rather than an imposition. In some cases family members worked together, for instance on building a house and in other cases family members had to be on hand for fitting of clothes or to try out techniques to be taught. The ability to enhance personal relations by the gift of crafts was an apparent gratification for the craft teachers. Where the curriculum suggests a 
vocational relevance to the productive sphere the teachers have a domestic or reproductive sphere orientation.

\section{Conclusion: Distance Between Close Relatives}

I mentioned earlier that the curriculum rationales for the three subjects have been converging. More precisely an emphasis on creativity had been extended from art to crafts and objectives relating art, design and craft were added to the art curriculum. That is, the boundaries of the vocational and aesthetic traditions have become blurred. Furthermore, explicit demands for integration were made in the 1977 curriculum. This was part of a general trend toward subject matter integration (Namskra fyrir barnaskola 1950, Adainamskra Grunnskola 1977, 1989).

In practice the art and craft subjects have not integrated and teachers did not seem keen on the idea of integration. They honor an ancient Norse proverb that stipulates a certain distance; let there be a brook between friends, a river between relatives. The explicit reasons teachers gave me for the lack of art and craft integration were mainly institutional constraints such as timetabling, physical space limitations, difficulty covering the curriculum within the time allotment, lack of planning time, etc., but other comments revealed underlying reasons. Firstly, groups perceive their subject as marginal: they are afraid to lose any further ground through integration. The main assumption is that any movement will further erode a curriculum base already perceived as weak.

Secondly, and undoubtedly related, is a basic distrust or even dislike of the other cousins. This stems from their different upbringing and differing traditions. Art teachers were traditionally trained in an art college of education. Art teachers characterized craft teachers as unlike them, as being more conformist, less creative, not artistic or aesthetically inclined. The sentiment was echoed by craft teachers' belief that art teachers are culture snobs. Wood and metalwork teachers did not have much respect for "the women" and in this context that always means textile teachers, whom they see as conservative old maids. The textile teachers have difficulty relating to the wood and metalwork teachers because of a perceived lack of professional commitment, particularly to curriculum planning and cooperation. All parties go about their business resolutely ignoring their poor relations. This of course does not help their marginal status and effectively blocks any 
concerted effort at advocacy, and much curriculum development is impossible in such a besieged atmosphere.

The relationship mapped on the curricular family tree is not borne out in the life histories of art and craft teachers. This is an example of how we as researchers of curricula and instruction must bear in mind that we are not simply researching concepts, but the manifestation of concepts in the practice of people.

\section{References}

B.C. Ministry of Education (1985). Elementary Fine Arts Curriculum Guide/Resource Book. Victoria: Queens Printer for British Columbia.

Barone, T. (1983) Things of Use and Things of Beauty. The Story of the Swain County High School Arts Program In E. Eisner (ed.) The Educational Imagination (2nd ed.) (pp. 275-295).

Berliner, D.C. (1984). The Half-full Glass: A Review of Research About Teaching. In P. L. Hosford (ed.) Using What We Know About Teaching. Alexandria VA: A.S.C.D.

Dow, I. I., Whitehead, R.Y. and Wright, R.L (1984). Curriculum Implementation: A Framework for Action. Ontario Public School Teachers' Federation.

Doyle, W. \& Ponder, G. (1977). The Ethics of Practicality: Implications for Curriculum Development. In A. Molnar and J. Zahorik (eds.) Curriculum Theory. (pp. 74-81) Washington: A.S.C.D.

Ehlstain, J. B. (1981). Public Man Private Woman: Women in Social and Political Thought. Princeton University.

Eisner, E. (1984). Alternative Approaches to Curriculum Development in Art Education. Studies in Art Education 25(4), 259-264.

Fullan, M. (1982) The Meaning of Educational Change. Toronto: O.I.S.E.

Gisli Agust Gunnlaugsson (1988). Family and Household in Iceland $1801-1930$. Studies in the Relationship Between Demographic and Socioeconomic Development, Social Legislation and Family and 
Household Structures. Studia Uppsalensia 154. Uppsala,

Sweden: Institute of history, Uppsala University.

Goodlad, J.I. and associates (1979). Curriculum Inquiry. N.Y.:McGraw-Hill.

Gray, J.U. \& MacGregor, R.N. (1987)/ \{PROACTA: Personally Relevant Observations About Art Concepts and Teaching Activities. Canadian Review of Art Education 14, 23-33.

Gudmundur Finnbogason (1905). Skyrsla um fraedslu barna og unglinga veturinn 1903-1904. (Report on the education of children 1903-1904). Reykjavik: Gutenberg.

Gudrun Heigadottir (1991). Halldora Bjarnadottir and the Development of Textiles at a school in Iceland. Nordisk Konferens isioyd Rapport. Gothenburg: University of University.

Gudrun Helgadottir (1993) Art, sloyd and the good life. Presentation National Art Education Association, Chicago III. April.

Ingolfur A Johannesson (1983). Menntakerfi i motun. (Education system in formation). Published thesis. Reykjavik: University of Iceland.

Lydur Bjornsson (1981). Agrip af sogu kennaramenntunar a Isiandi - (Overview of the history of teacher education) Smarit Kennarahaskoians og Idunnar 8. Reykjavik: Idunn.

Menntamalaraduneytid (1950) Namskra i teiknun (Curriculum in drawing) Reykjavik: Gutenberg.

Menntamalaraduneytid (1977). Adalnamskra Grunnskola. Myn og hand menntt. (Elementary school curriculum. Art and Craft). Reykjavik: Gutenberg.

Menntamalaraduneytid (1989). Adalnamskra Grunnskola. (Elementary school curriculum). Reykjavik: Gutenberg.

Nordic Art Teachers' Union (1987). Comparative Summary. In Nordic paradise? Lund, Sweden: Wallin and Dalholm.

Petterson, S. \& Asen, G. (1989). Bildundervisningen och det pedagogiska rummet. Tradtioner, forestallningar och 
undervisningsprocess inom skolamnet teckning/bild i grundskolan. (Art education and the pedagogical space).

Stockholm: Hogskolan for lararutbildning, Institutionen for Pedagogik.

Washington State Technology Education Curriculum Development Project (1990). Technology education. Basic learning for living in the twenty-first century. Vol. 1.

Zais, R.S. (1976). Curriculum: Principles and Foundations.

N.Y.: Harper \& Row. 